Отримано: 23 травня 2018 р.

Прорецензовано: 29 травня 2018 р.

Прийнято до друку: 01 червня 2018 р.

e-mail: olena.parubets@gmail.com

DOI: $10.25264 / 2311-5149-2018-9(37)-21-24$

Парубець О. М. Дослідження проблем та перспектив розвитку експорту транспортних послуг України. Наукові записки Національного університету «Острозька академія». Серія «Економіка» : науковий журнал. Острог : Вид-во НаУОА, червень 2018. № 9(37). C. 21-24.

Парубець Олена Миколаївна,

доктор економічних наук, доцент, професор кафедри фінансів, банківської справи та страхування,

Чернігівський національний технологічний університет

\title{
ДОСЛІДЖЕННЯ ПРОБЛЕМ І ПЕРСПЕКТИВ РОЗВИТКУ ЕКСПОРТУ ТРАНСПОРТНИХ ПОСЛУГ УКРАЇНИ
}

У статті проведено аналіз обсягу і структури експорту транспортних послуг. Виявлено проблеми розвитку у сфері експорту транспортних послуг, основними серед яких поряд із незадовільною якістю транспортної інфраструктури є низький рівень упровадження сучасних інформачійних технологій на транспорті й інформатизаиії прочесу надання транспортних послуг.

Ключові слова: експорт, імпорт, ефективність, транспортні послуги, інформаційні технології.

Парубец Елена Николаевна,

доктор экономических наук, дочент, профессор кафедры финансов, банковского дела и страхования,

Черниговский национальный технологический университет

\section{ИССЛЕДОВАНИЕ ПРОБЛЕМ И ПЕРСПЕКТИВ РАЗВИТИЯ ЭКСПОРТА ТРАНСПОРТНЫХ УСЛУГ УКРАИНЫ}

В статье проведено анализ объемов и структуры экспорта транспортных услуг. Выявлено проблемы развития в сфере экспорта транспортных услуг, основными среди которых наравне с неудовлетворительным качеством транспортной инфраструктуры выступают низкий уровень внедрения современных информационных технологий на транспорте и информатизации проиесса предоставления транспортных услуг.

Ключевые слова: экспорт, импорт, эффективность, транспортные услуги, информационные технологии.

\author{
Olena Parubets, \\ Doctor of Economic Sciences, Associate Professor, Professor of the Department of Finance, Banking and Insurance, \\ Chernihiv National University of Technology, Chernihiv
}

\section{RESEARCH OF PROBLEMS AND PROSPECTS FOR THE DEVELOPMENT OF EXPORT OF TRANSPORT SERVICES IN UKRAINE}

The article analyzes the volume and structure of export of transport services. The problems of the development of export of transport services have been revealed. The main problems are the unsatisfactory quality of transport infrastructure, the low level of implementation of modern information technologies in transport and informatization of the process of provision of transport services.

Key words: export, import, efficiency, transport services, information technologies.

Постановка проблеми. Зростання обсягу експорту транспортних послуг має пріоритетне значення для підвищення ефективності використання транспортного потенціалу України, розширення географії пасажиро- і вантажоперевезень, надходженні валютної виручки, збільшення обсягу ВВП. В умовах політичної, економічної, фінансової кризи спостерігають падіння попиту на продукцію виробничого призначення, імпортні товари, туристичні послуги, що обумовлює зниження обсягу транспортних послуг під час зростання витрат на здійснення міжнародних перевезень завдяки інфляційним коливанням, девальвації національної валюти. Для забезпечення конкурентоспроможності на міжнародному ринку транспортних послуг вітчизняні перевізники повинні відповідати ряду вимог щодо зручності, місткості, комфортабельності, терміну експлуатації транспортних засобів і їх відповідності вимогам екологічності, надійності і безпеки. Водночас пріоритетне значення має розвиток транспортної та логістичної інфраструктури, відповідності доріг показникам рівності, швидкості руху, оснащеності сучасними приладами спостереження і контролю тощо. 
Аналіз останніх досліджень і публікацій. Науково-теоретичні аспекти стосовно дослідження проблем і перспектив розвитку експорту транспортних послуг відображені у великій кількості наукових праць.

Так, на думку А. С. Маловичко, основними проблемами на шляху розвитку експорту транспортних послуг виступають низький технічний рівень рухомого складу, високий рівень податкового навантаження на перевізників та неефективна державна митна політика [1, с. 128].

Автори роботи [2], досліджуючи експортний потенціал ринку послуг автомобільного транспорту, наголошують на необхідності розвитку державної підтримки експорту таких послуг у таких напрямах як покращення фіскального режиму й інвестиційного клімату, посилення інноваційної спрямованості розвитку транспортної інфраструктури, створення вільних економічних зон тощо.

Однак в умовах розвитку цифрової економіки, інформатизації суспільства збільшення обсягу експорту транспортних послуг напряму залежить від використання сучасних інформаційних технологій на транспорті, що потребує проведення подальших досліджень у цьому напрямі.

Метою статті є дослідження обсягів і структури експорту транспортних послуг, виявлення основних проблем, що перешкоджають розвитку міжнародного транспортного співробітництва й обгрунтування напрямів їх усунення.

Досягнення поставленої мети потребує вирішення таких завдань:

- проведення аналізу обсягу і структури експорту й імпорту транспортних послуг;

- дослідження рівня розвитку транспортного співробітництва України з країнами $Є C$;

- виявлення проблем, що заважають розвитку експорту транспортних послуг та обгрунтування напрямків їх усунення.

Виклад основного матеріалу. Перш ніж визначити основні проблеми, що перешкоджають збільшенню експорту транспортних послуг, проведемо аналіз його обсягів за період 2012-2016 рр., результати якого наведені в таблиці 1.

Таблиия 1

Динаміка експорту транспортних послуг, тис. дол. США

\begin{tabular}{|l|c|c|c|c|c|}
\hline \multirow{2}{*}{$\begin{array}{c}\text { Транспортні послуги за видами транспорту та тран- } \\
\text { спортної діяльності }\end{array}$} & \multicolumn{5}{|c|}{ Роки } \\
\cline { 2 - 6 } & $\mathbf{2 0 1 2}$ & $\mathbf{2 0 1 3}$ & $\mathbf{2 0 1 4}$ & $\mathbf{2 0 1 5}$ & $\mathbf{2 0 1 6}$ \\
\hline Автомобільний & 452364,2 & 478396,4 & 459623,7 & 249071,0 & 237949,1 \\
\hline Залізничний & 1586646,9 & 1613856,3 & 1098830,7 & 751254,1 & 561118,6 \\
\hline Морський & 1241240,3 & 1123732,6 & 850878,8 & 735935,8 & 661619,1 \\
\hline Річковий & 63091,2 & 42299,6 & 46342,3 & 44494,8 & 29944,4 \\
\hline Повітряний & 1510704,9 & 1333178,2 & 1071262,5 & 853618,5 & 882840,3 \\
\hline Трубопровідний & 3248222,6 & 3335629,6 & 2207902,0 & 2258041,9 & 2630686,4 \\
\hline Інші допоміжні та додаткові транспортні послуги & 396577,3 & 333723,9 & 330069,7 & 341649,9 & 262868,2 \\
\hline
\end{tabular}

Джерело: складено автором на основі [3].

За підсумками 2016 р. у структурі експорту транспортних послуг найбільшу питому вагу займали такі країни: Російська Федерація - 52,3\%, Великобританія - 4,5\%, Швейцарія - 4,4\%, Німеччина, Туреччина - 3,0\%, Об’єднані Арабські Емірати - 2,6\%, США - 2,2\%, Кіпр - 1,8\% [3]. В умовах розвитку євроінтеграційних процесів постає необхідність налагодження ефективної транспортно-економічної співпраці з країнами ЄС. Аналіз статистичних даних указує на те, що частка експорту транспортних послуг до більшості країн ЄС складає менше одного відсотку. Так, обсяг експорту зазначених послуг із країнами $\mathrm{EC}$, які межують із Україною і поєднанні мережею міжнародних транспортних коридорів, у звітному році складав: Польща - 1,2\%; Румунія - 0,2\%, Словаччина - 0,4\%, Угорщина - 0,8\% [3].

Позитивною є тенденція перевищення обсягу експорту над обсягом імпорту транспортних послуг. Аналіз обсягу імпорту транспортних послуг України наведено в таблиці 2.

Імпорт транспортних послуг Україною, тис. дол. США

Таблиия 2

\begin{tabular}{|l|c|c|c|c|c|}
\hline \multirow{2}{*}{\multicolumn{1}{|c|}{ Транспортні послуги за видами транспорту }} & \multicolumn{5}{|c|}{ Роки } \\
\cline { 2 - 6 } & $\mathbf{2 0 1 2}$ & $\mathbf{2 0 1 3}$ & $\mathbf{2 0 1 4}$ & $\mathbf{2 0 1 5}$ & $\mathbf{2 0 1 6}$ \\
\hline Автомобільний & 194594,4 & 197221,1 & 189804,7 & 91845,4 & 114860,7 \\
\hline Залізничний & 643002,6 & 626973,1 & 431305,2 & 287002,5 & 259877,0 \\
\hline Морський & 202830,1 & 195795,1 & 243651,7 & 191729,0 & 141180,7 \\
\hline Річковий & 372,6 & 360,8 & 1087,6 & 600,8 & 351,1 \\
\hline Повітряний & 641287,7 & 643550,4 & 431037,6 & 466937,6 & 3574465,0 \\
\hline Трубопровідний & 877,5 & 3512,2 & 52588,0 & 98123,3 & 87229,5 \\
\hline Інші допоміжні та додаткові транспортні послуги & 17986,0 & 33714,4 & 15717,7 & 11332,6 & 20863,9 \\
\hline
\end{tabular}

Джерело: складено автором на основі [3]. 
Серед країн $Є С$ найбільшими імпортерами транспортних послуг в Україну є Німеччина - 14,3\%, Великобританія $-6,7 \%$, Словаччина - 9,7\%, Польща $-3,8 \%$, Кіпр - 3,4\%. Щодо найближчих країн-сусідів ситуація протилежна, тобто Україна більше імпортує транспортних послуг, ніж експортує, за винятком Румунії, де частка імпорту складає всього $0,1 \%$. Обсяг імпорту транспортних послуг у 2016 р. з Польщі складав $-6,2 \%$, Словаччини - 9,7\%, Угорщини - 2,9\% від їх загального обсягу [3].

Вищенаведені показники свідчать про неефективне використання транспортного потенціалу України, яка, будучи частиною загальноєвропейської транспортної мережі, має важливе транзитне значення на шляху сполучення Європа-Азія, а також можливостей і перспектив інтеграції національного транспортного сектору до європейської транспортної системи та спільного Європейського економічного простору.

Однією з головних проблем, що стає на заваді збільшення обсягу експорту транспортних послуг, $є$ незадовільний рівень транспортної інфраструктури і її невідповідність міжнародним вимогам і стандартам. про що наглядно свідчить місце України в міжнародних рейтингах.

Згідно з рейтингом глобальної конкурентоспроможності, представленому Світовим економічним форумом (див. таблицю 3), Україна у 2017-2018 рр. покращила свої позиції на чотири пункти, порівняно 3 попереднім періодом.

Інфраструктурна складова Індексу глобальної конкурентоспроможності

\begin{tabular}{|l|c|c|c|}
\hline \multicolumn{1}{|c|}{ Позиції України } & $\begin{array}{c}\text { 2015-2016 pp. } \\
\text { (місце серед 140 } \\
\text { країн світу) }\end{array}$ & $\begin{array}{c}\text { 2016-2017 pp. } \\
\text { (місце серед 138 } \\
\text { країн світу) }\end{array}$ & $\begin{array}{c}\text { 2017-2018 pp. } \\
\text { (місце серед 137 } \\
\text { країн світу) }\end{array}$ \\
\hline Індекс глобальної конкурентоспроможності & 79 & 85 & 81 \\
\hline Транспортна інфраструктура & 91 & 91 & 87 \\
\hline Якість усієї інфраструктури & 82 & 88 & 88 \\
\hline Якість доріг & 132 & 134 & 130 \\
\hline Якість залізничної інфраструктури & 28 & 34 & 37 \\
\hline Якість портової інфраструктури & 108 & 96 & 93 \\
\hline Якість інфраструктури повітряного транспорту & 97 & 103 & 92 \\
\hline
\end{tabular}

Джерело: складено автором за даними [4].

Не дивлячись на незначне зростання рейтингу транспортної інфраструктури, показники, що характеризують їі якість, залишаються на досить низькому рівні за винятком якості залізничної інфраструктури. Проблемною протягом періоду, який аналізуємо, є якість доріг, за якою наша держава займає найнижчі позиції в рейтингу.

Не найкращу ситуацію спостерігаємо і у сфері транспортно-логістичного обслуговування споживачів транспортних послуг. Підтвердженням цього $є$ показники індексу ефективності логістики, наведені в таблиці 4. Відповідно до рейтингу логістики за 2016 р. Україна суттєво погіршила свої позиції майже за всіма показниками, що входять до його складу. Більш високе значення серед яких, не дивлячись на зменшення на 2 пункти у 2016 р., порівняно 32015 р., має своєчасність доставки вантажів у пункти призначення. Недостатній рівень розвитку логістичної інфраструктури перешкоджає активізації транспортно-економічного співробітництва України з країнами ЄС.

Місце України в індексі ефективності логістики (LPI)

\begin{tabular}{|l|c|c|c|c|}
\hline \multicolumn{1}{|c|}{ Показники } & \multicolumn{3}{c|}{ Роки } \\
\cline { 2 - 5 } & $\mathbf{2 0 1 0}$ & $\mathbf{2 0 1 2}$ & $\mathbf{2 0 1 4}$ & $\mathbf{2 0 1 6}$ \\
\hline Кількість країн світу, для яких визначався рейтинг & 155 & 155 & 160 & 160 \\
\hline Місце України в рейтингу, зокрема за складовими & 102 & 66 & 61 & 80 \\
\hline Ефективність митної обробки вантажу & 135 & 88 & 69 & 116 \\
\hline Якість логістичної інфраструктури & 79 & 70 & 71 & 84 \\
\hline Можливості організації міжнародних вантажовідправлень & 84 & 83 & 67 & 95 \\
\hline Компетентність і якість логістичних послуг & 77 & 61 & 72 & 95 \\
\hline Можливість контролю і відстеження вантажів & 112 & 50 & 45 & 61 \\
\hline Своєчасність доставки вантажів у пункти призначення & 114 & 68 & 52 & 54 \\
\hline
\end{tabular}

Джерело: складено автором на основі [5].

На стан експорту транспортних послуг, насамперед, впливає структура і тенденції розвитку міжнародної торгівлі. Виходячи з цього, збільшення обсягів експортної діяльності на ринку транспортних послуг потребує врахування тенденцій розвитку світової торгівлі в майбутньому, які базуються на активізації використання цифрових технологій і інновацій, масової персоналізації товарів і послуг, зменшенні витрат на переміщення товарів та зростанні швидкості торгівлі [6]. 
В умовах розвитку штучного інтелекту, новітніх інформаційних технологій, Інтернету-речей, Смарттуризму комунікаційна взаємодія транспортного сектору з іншими економічними агентами все більше переходить у віртуальну сферу. Розширення спектру застосування нових інформаційних технологій у процесі надання транспортних послуг стає запорукою підвищення їхньої конкурентоспроможності та збільшення обсягу експорту. Водночас застосування інформаційних, зокрема інтернет-технологій, при взаємодії різних видів транспорту не потребує їх територіальної близькості, що дозволяє обслуговувати споживачів, сконцентрованих у різних географічних зонах [7, с. 45].

На заваді розвитку інформаційних технологій у транспортному секторі України постають проблеми, пов'язані із: відсутністю достатнього обсягу ресурсів на впровадження новітніх інформаційних технологій підприємствами транспорту; зниженням показників прибутковості суб'єктів господарювання та низьким рівнем доходів населення як основних споживачів транспортних послуг; відсутністю дієвих механізмів транспортно-економічного співробітництва в напрямі збільшення прямих іноземних інвестицій у модернізацію і переоснащення інформаційної структури вітчизняного транспорту.

Швидке поширення електронного бізнесу й електронної комерції на фоні затримки впровадження інформаційно-комунікаційних технологій на транспорті може призвести до суттєвого відставання його розвитку і неспроможності задовольнити зростаючі вимоги споживачів транспортних послуг. Пошук і розширення кола споживачів транспортних послуг як усередині країни, так і за її межами, потребує диверсифікації спектру електронних послуг, які підприємства транспорту можуть надавати за допомогою мережі Інтернет і соціальних мереж. У зв'язку з цим необхідне широке впровадження і використання на транспорті електронної логістики, відеотерміналів, технологій Big Data, GPS - моніторингу, GPS - навігації, Смарт-тахографів, платіжного сервісу Android Рay, порталу Amazon тощо.

Ураховуючи специфіку транспорту, в онлайн-режимі можуть надаватися тільки послуги, що безпосередньо не пов'язані з переміщенням вантажів і перевезенням пасажирів. Поряд із безперечними перевагами таких послуг, які полягають у зменшенні матеріальних, трудових, часових витрат, а також підвищенні оперативності, відкритості та зручності надання, таким послугам притаманні і суттєві недоліки. Основними серед них є: зростання вірогідності порушення роботи інформаційних систем суб'єктів транспортної діяльності та їх безпосередніх клієнтів; можливість здійснення кібератак, особливо на об'єкти критичної інфраструктури, до яких належить і транспорт у разі браку розвиненого ринку кіберстрахування в Україні.

Збільшення обсягу експорту транспортних послуг потребує державної підтримки та розвитку державно-приватного партнерства в напрямі впровадження інформаційно-комунікаційних технологій на транспорті. Це дасть змогу не тільки забезпечити ефективне використання транзитного потенціалу України, але і стане однією із точок економічного зростання держави.

Висновки. Отже, розвиток інформаційної економіки зумовлює внесення суттєвих змін до стратегії зовнішньоекономічної політики держави у зв'язку з процесами поступового зменшення обсягу експорту традиційних послуг, до складу яких належать і транспортні, та збільшення попиту і пропозиції на інформаційно-телекомунікаційні послуги. В таких умовах реалізація транспортних послуг на внутрішньому i зовнішньому ринках потребує їх інформатизації відповідно до зміни потреб споживачів і рівня використання останніми інформаційних технологій.

\section{Література:}

1. Маловичко А. Експорт транспортних послуг. Економічний аналіз. 2011. Вип. 8. Ч. 1. С. 125-128. URL : http://econa.at.ua/Vypusk_8/p1/malovichko.pdf.

2. Замлинський В. А., Коваль В. В., Котлубай В. О. Стан та перспективи розвитку експортного потенціалу ринку послуг автомобільного транспорту. Економіка та суспільство. 2017. № 9. С. 210-214. URL : http:// economyandsociety.in.ua/journal/9_ukr/36.pdf.

3. Транспорт і зв’язок України: статистичний збірник. К. : Державна служба статистики України. 2016. $185 \mathrm{c}$.

4. World Economic Forum. URL : http: https://www.weforum.org/reports.

5. Logistics Performance Index - LPI 2016. The World Bank. URL : http://lpi.worldbank.org.

6. Український експорт: підсумки 2016 року та погляд в майбутнє. Інститут економічних досліджень та політичних консультацій. URL : http://www.ier.com.ua/ua/publications/articles?pid=5503.

7. Парубець О. М. Розробка методики оцінки рівня інформатизації транспортного сектору України як запорука його конкурентоспроможності. Технологический аудит и резервы производства. 2016. № 4/5 (30). C. $42-46$. 